\section{After the Crash}

\section{Thomas Daniell}

\author{
Review by Andrew Barrie
}

Western architectural critics are tempted to write about Japan in ways they would describe architecture from few other countries. Only a very brave critic would attempt to define the influence of Church of England theology on Norman Foster's work or to propose the Hagia Sophia as a 'prototype' that still informs the work of contemporary European architects. Architectural commentators, however, have been perfectly willing to discuss Toyo Ito's architecture in relation to Buddhist beliefs or to suggest the roots of SANAA's design for the twenty-firstJapan centure.

To be fair to Western commentators, they have often been led astray by the locals. The tendency to interpret Japan's contemporary architecture through relatively obscure parts of its cultural history or architectural heritage began in the 1920s, when Japan's increasingly nationalist authorities demanded new buildings be built according to an 'oriental taste'. The progressive Japanese architects then advocating European-style modernism began, largely as a political strategy to make their ideas more palatable, promoting an interpretation of certain strain of Japanese traditional architecture as a form of proto-modernism. These ideas were picked up and disseminated by Bruno Taut and others, and Japan's traditions became one of the few vernacular reference points deemed compatible with modernist ideals, which otherwise sought a clean break with the past.

This use of Japanese culture took a new turn in the 1970s, when a new generation of commentators and architects under the leadership of Arata Isozaki began expounding the importance of hitherto obscure spiritual and anthropological concepts. This dubious anthropology was denounced at the time as an attempt by the architects involved to exoticize Japanese architecture, and by extension heir own work but the a foothold and were repeated so regularly as to become clichés.

Of course, there are connections between Japan's cultural anthropology and it contemporary architecture, but locating these often requires looking past much more inmediate influences and pervasive ideas. morivectural (n) graphic changes in the society, and the character of the local construction industry. Japan's slow-motion economic crash in the early 1990s made apparen the frivolousness of much of what had gone before and marked the emergence of a new seriousness in Japanese architecture. Architects dropped the wildly experimental approach that characterized the 1980s, and began focussing on the objective realities of Japan's social, economic and urban situation.
It is this clear-headed reconsideration of architectural fundamentals that provides the key themes for Thomas Daniell's After the Crash: Architecture in PostBubble Japan. As befits its serious subject matter, After the Crash is a sober volume. Within its simple black-on-white cover, the 200-odd A5 pages are sparely illustrated with black-and-white photos and drawings; the text has priority. The tex consists of revised versions of 25 of Daniell's essays and articles written for a variety of architecture and design journals. As befits a period in which big issues are earnestly reconsidered, these essays offer lucid critique and insightful observation. Daniell describes how a good deal of what seems to foreign eyes most extraordinary about contemporary Japanese architecture has emerged from pragmatic responses to the unique constraints of the Japanese context. He explain how, for example the highly sculptural forms employed in small houses often result sing often result simply from the town sect: the intense pressue to maxize ocupiable space on ing volumes into the precise angular geometry of the town-planning recession plane envelope.

After the Crash is one of the first English-language books to survey the Japanese scene published since the millennium. As an anthology of essays, some very short, the book is a montage of scenes rather than a comprehensive survey. A number of the essays focus on the work of relatively minor figures (there are two essays on the work of Kiyoshi Sei Takeyama) or on minor works by major figures (Waro Kishi's Hutong House). While it covers the key themes driving contemporary Japanese architecture, as a fairly compact book it necessarily omits many of the key figures (including Kengo Kuma, Tadao Ando, Shigeru Ban) and key works (such as Riken Yamamoto's university campuses, Yoshio Taniguchi's Gallery of Horyuji Treasures). However, if the book is paired with another recent publication with which Daniell was involved - the "Parallel Nippon" issue of the Japan Architect which surveys key Japase buldings from 1996 to 2006 - the (the provide what is currently the best record of the post-bubble era.

After the Crash cements Daniell's place as one of the most articulate and astute interpreters of the Japanese architecture scene for Western audiences. Within the necessarily partial coverage created by the book's anthology format, it concisely captures a moment in Japan's architectural history. As Daniell acknowledges in his introduction, however, that moment is already receding into the past. Japan seems at last to be emerging from post-bubble gloom, and the themes of Daniell's essays are giving way to new ideas and approaches. A new generation of architects is emerging whose work, while moderated by the pragmatism of the last decade, returns to the experimental attitude of the bubble era. As these new alignments begin to coalesce, let us hope that commentators can follow Daniell's lead and escape the clichés of the past.

References

Parallel Nippon: Contemporary Japanese Architecture 1996-2006 (2007). Japan Architect, 65 (Spring) 